\title{
Gationic Cyclization Involving a Remote Allene Function in the Trifluoroethanolysis of Hepta-5,6-dienyl Toluene-p-sulphonate
}

\author{
By Michael H. Sekera, Ben-Avi Weissman, and Robert G. Bergman* \\ (Gates and Crellin Laboratories of Chemistry, California Institute of Technology, Pasadena, California 91109)
}

\section{Summary The remote allene function participates efficiently in the trifluoroethanolysis of hepta-5,6-dienyl toluene- $p$-sulphonate, leading to the cyclized 2-methyl- enecyclohexyl cation.}

CATIONIC cyclization reactions of general type $(\mathbf{1}) \rightarrow(2)$ play a central role in the biogenesis of cholesterol and other steroidal compounds, ${ }^{1}$ and are also useful in syntheses of mono- and poly-cyclic molecules. ${ }^{2}$ Recently it has been<smiles>[X]C[C@@H]1[CH+]C([R])CCC1</smiles>

(1)

(2)<smiles>[X]C(C)CCCC#C</smiles><smiles>[R]C1=CCCCC1C</smiles>

(4)<smiles>[R]C=C1CCCC1[Y4]</smiles>

(5)<smiles>[X]CCCCC=C=C</smiles>

(6)<smiles>C=C1CCCCC1</smiles>

$x^{-}$

discovered ${ }^{3}$ that remote triple bonds can participate in olefinic cyclizations ${ }^{4}[(\mathbf{3}) \rightarrow(\mathbf{4})+(\mathbf{5})]$, and this reaction has also been found to be synthetically useful. ${ }^{4}$ Since allenes

are quite reactive in electrophilic additions, ${ }^{\mathbf{5}}$ and cyclization involving an allenic function $[e . g$. (6)] should lead to a relatively stable allylic cation (7), it is surprising that no examples of this transformation are in the literature. We report that, under appropriate conditions, the reaction $(6) \rightarrow$ (7) takes place.<smiles>C=C1CCCCC1OCC(F)(F)F</smiles>

(8)

(9)

Scheme

The tosylate $\left(6 ; \mathrm{X}=p-\mathrm{MeC}_{6} \mathrm{H}_{4} \cdot \mathrm{SO}_{2}\right)$ was prepared from hex-5-en-I-ol. ${ }^{6}$ Solvolysis of (6) in acetic acid at $60^{\circ}$ gave mainly starting alcohol, but solvolysis in the weakly nucleophilic 2,2,2-trifluoroethanol ${ }^{7}$ led to $>90 \%$ cyclization. The mixture of trifluoroethyl ethers obtained (ca. $65 \%$ yield) consisted of uncyclized material $\left(6 ; \mathrm{X}=\mathrm{OCH}_{2}-\right.$ $\mathrm{CF}_{3}, 5 \%$ ), the two allylic isomers (8) (45\%) and (9) $(45 \%)$, and unidentified material $(5 \%)$. The structures of the cyclized products were inferred from spectral data, and confirmed by independent syntheses. ${ }^{8}$ Kinetic studies 
$\left(60^{\circ}\right.$; trifluoroethanol) showed that the rate constant for ionization of (6) was $8.15 \times 10^{-7} \mathrm{~s}^{-1}$, which compares with $k=4.0 \times 10^{-7} \mathrm{~s}^{-1}$ for $\mathrm{n}$-heptyl tosylate.

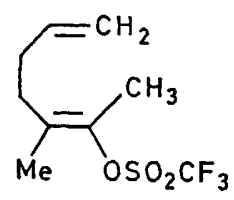

(10)

Despite major structural differences in starting materials and generated cations, the cyclization behaviour of (6) is strikingly similar to that of a number of other substrates. Sulphonates $\left(\mathbf{1} ; \mathrm{R}=\mathrm{H}, \mathrm{X}=p-\mathrm{NO}_{2} \cdot \mathrm{C}_{6} \mathrm{H}_{4} \cdot \mathrm{SO}_{2}\right),(3 ; \mathrm{R}=\mathrm{H}$, $\left.\mathrm{X}=p-\mathrm{MeC}_{6} \mathrm{H}_{4} \cdot \mathrm{SO}_{2}\right)$, and (10) all give low proportions of cyclization products in acetic acid but greater amounts in solvents of lower nucleophilicity, such as trifluoroethanol and trifluoroacetic acid; all show borderline participation of the remote unsaturation (Scheme) in the transition state for ionization. . $^{3 \mathrm{a}, 6,8,10}$

From a synthetic point of view, cyclization involving a remote allene function should complement other cyclization systems. It also raises the possibility of generating selective enantiomerism at the asymmetric centres on the new $\mathrm{C}-\mathrm{C}$ bond using optically active allenic substrates. Mechanistically, this study appears to support Peterson's suggestion $^{3 a}$ that the transition states for cyclizations bear little resemblance to the final cations generated. In the allene case, most of the charge probably still resides at $\mathrm{C}-1$ as this atom interacts with the remote $\pi$ system, and little C-6-C-7 rotation takes place until the reaction is well past the transition state. $\dagger$

We thank the National Institutes of Health, the Alfred P. Sloan Foundation, and the Camille and Henry Dreyfus Foundation for support.

(Received, 26th June 1973; Com. 919.)

† H. T. Hall and W. S. Johnson (personal communication; see H. T. Hall, Ph.D. Dissertation, Stanford University, 1973), have observed the formation of trans-fused bicyclic allylic alcohols on treatment of trans-3-isopropylidene-2,6-dimethyldodeca-6,10,11trien-2-ol with, e.g., trifluoroacetic acid in $\mathrm{CH}_{2} \mathrm{Cl}_{2}$ at $-78^{\circ}$. The results of this study are entirely analogous to our own findings.

1 R. B. Clayton, Quart Rev., 1965, 19, 168.

2 W. S. Johnson, Accounts Chem. Res., 1968, $1,1$.

3 (a) P. E. Peterson and R. J. Kamat, J. Amer. Chem. Soc., 1969, 91, 4521; (b) M. Hanack, C. E. Harding, and J.-L. Derocque, Ber., $1972,105,421$

4 (a) W. S. J ohnson, M. B. Gravestock, R. J. Parry, R. F. Myers, T. A. Bryson, and D. Howard Miles, J. Amer. Chem. Soc., 1971, 93, 4330 ; (b) P. T. Lansbury and G. E. DuBois, Chem. Comm., 1971, 1107.

5 (a) M. L. Poutsma, J. Amer. Chem. Soc., 1971, 93, 440; (b) K. Griesbaum, Angew. Chem., 1966, 5, 533.

- P. D. Bartlett, W. D. Closson, and T. J. Cogdell, J. Amer. Chem. Soc., 1965, 87, 1308.

7 (a) W. S. Trahanovsky and M. P. Doyle, Tetrahedron Letters, 1968, 2155; (b) M. D. Bentley and J. A. Lacadie, ibid., $1971,741$.

8 M. Mousseron, R. Jaquier, and A. Fontaine, Bull. Soc. chim. France, 1956, 1737.

9 W. D. Closson and D. Gray, J. Org. Chem., 1970, 35, 3737.

${ }_{10}$ (a) T. C. Clarke, D. R. Kelsey, and R. G. Bergman, J. Amer. Chem. Soc., 1972, 94, 3626; (b) T. C. Clarke and R. G. Bergman, ibid., p. 3627. 